\title{
Does Foreign Ownership Affect Investment Decisions of Manufacturing Companies in Indonesia?
}

\author{
Ahmad Cahyo Nugrohoㅇ, Muhammad Firdaus², Trias Andati², Tony Irawan ${ }^{2}$ \\ ${ }^{1}$ Ministry of Industry \\ Indonesia \\ ${ }^{2}$ Lecturer, School of Business, Bogor Agricultural University \\ Bogor, Indonesia \\ *Corresponding author's email: ac.nugroho999 [AT] gmail.com
}

\begin{abstract}
Premature deindustrialization phenomenon indicated by decreasing manufacturing industry share on the economy faster than expected. Its reflected on the national investment target achievement in the manufacturing sector. This study aims to analiyze the agency problem in investment decision of manufacturing industry in Indonesia by considering foreign ownership. The panel data method used with an annual period from 2007 to 2016 and 100 samples of manufacturing companies listed on the Indonesia Stock Exchange (IDX). This study shows that agency problems occur in indonesian manufacturing companies. Foreign ownership indirectly affects the investment of manufacturing companies reflect better control on management decision.
\end{abstract}

Keywords-Agency Problem, Foreign Ownership, Investments, Manufacturing.

\section{INTRODUCTION}

The World Bank data shows that manufacturing industry contribution on total economy in Indonesia is declining faster than Thailand and Malaysia. Declining process began in 2001 and has not even touched at a share rate of 30 percent. Malaysia and Thailand have reached even more than the 30 percent share before experiencing a decline in share. This indicates the occurrence of premature deindustrialization in Indonesia.

The investment realization in the manufacturing industry sector mostly dominated by investment in the form of foreign investment which reached 683.63 trillion IDR, or 68.58 percent of the total investment in the manufacturing industry sector with a total of 10,705 projects during 2010-2015. While domestic investment is only 244.46 trillion IDR, or 31.42 percent of the total investment of the non-oil and gas processing sector with a total of 3,851 projects during 2010-2015 (BKPM 2015). This illustrates that foreign investors are more dominant during investment activities in the manufacturing sector.

Based on data from Indonesia Stock Exchange (2015), Manufacturing companies have a fairly large proportion on the IDX and continue to increase, reaching 146 issuers or 28.02 percent of all listed companies on the IDX in 2015. In addition, the manufacturing sector was able to contribute 25\% to the IDX Composite in 2015.

Corporate governance has an important role on the company's performance. Byun et al. (2012) and Ammann et al. (2010) stated that corporate governance positively influences company value, which shows that corporate governance increases the company value. Corporate governance can be seen from several aspects, one of the examples is share ownership. Share ownership is closely related to the agency theory. Chen et al. (2013) and Lin (2011) shows that there will always be agency problems and asymmetric information on the study of share ownership. Lin (2011) research results show agency associations with control of share ownership can affect corporate finance and investment spending.

According to Chen (2013) there are differences in the management of companies between companies with government share ownership, family share ownership, and foreign ownership. With foreign investors in share ownership, a better management system is created due to new knowledge and technology that is included in the company (Guariglia and Yang 2015; Chen et al. 2014; Shin and Kim 2002). As in the study of Buckley et al. (2007) which shows that foreign direct investment tends to invest more in technology that makes the industry more intensive. Arnold and Javorsik (2009) stated 
that foreign ownership in manufacturing companies in Indonesia will increase productivity because there is a transfer of knowledge and technology, and foreign ownership which is easier to access financing.

Investment decisions are important decisions for the company because they will affect the company value (Andreou 2017; Vranakis and Chatzoglou 2012). Research about investment decision in Indonesia becomes more unique and interesting because of the financial constraints that will affect firm investment decisions such as in the research of Prasetyantoko (2007) and Hidayat (2010). Financial constraints occur in manufacturing companies in Indonesia due to the crisis. Manufacturing companies in Indonesia experience an insufficient liquidity to fund the current production costs (Dwor-Frecaut et al. 2000; Mydans 1998). Investment has a close relationship with agency theory. Messier et al. (2006) stated that agency problem is created by asymmetric information between principal and agent; and the occurrence of a conflict of interest between principal and agent.

\section{LITERATURE REVIEW}

Investment decisions on fixed assets commonly known as capital budgeting, reflect investment plans for long-term assets. Capital budgeting include overall process of analyzing project and deciding which projects will be included in the capital budget (Brigham and Houston 2009).

The essence of agency theory is the design of the right contract to aligning the interests of principals and agents in the event of a conflict of interest (Scott 1997). According to Eisenhard (1989), agency theory is based on three assumptions:

1. Assumptions about human nature

Self-interest, has limited rationality, and risk aversion.

2. Assumptions about organization

Conflict between members in the organization and the existence of Asymmetric Information (AI) between the principal and agent.

3. Assumptions about information. Information is seen as a commodity that can be traded.

Chen et al. (2013) examined whether government and foreign share ownership affect the efficiency of corporate investment. They used data from privatized companies in 64 countries. Government and institutional foreign ownership commonly associated with different levels of asymmetric information and agency problems. The study found strong evidence that government ownership undermines the sensitivity of investment opportunities, thereby increasing investment inefficiency. Otherwise, foreign ownership strengthens the sensitivity of investment opportunities, thereby increasing investment efficiency. In addition, Chen et al. (2013) found that the relationship between foreign ownership and investment efficiency is stronger when the government releases control and governance levels of government institutions are weaker.

Limanli (2015) examines the determinants or factors that influence R \& D investment decisions in Turkey. The research shows that sales, subsidies, share of foreign ownership, competition incentives, scale of enterprise, domestic and foreign trade shares are important factors that influence the possibility of investment in R \& D. Limanli's (2015) study have resulted in inconsistencies in results on foreign ownership variables. In 2008 the results of the study showed that foreign ownership had a negative effect on investment. This happened to foreign owners who prefer to invest R \& D in their home countries and transfer their innovations abroad. Foreign ownership variables have a positive effect on R \& D investment. These results confirm according to the hypothesis that larger companies allow easier access to funding.

Prastyantoko (2007) who studies foreign ownership and corporate investment shows that foreign ownership does not affect investment. Foreign ownership tends to delay long-term investment commitments during the 1997 financial crisis in Indonesia. Ownership of foreign shares has a lower commitment to long-term investment (fixed assets) than domestic stock ownership, although spending on short-term investments (inventory) is higher than domestic shareholdings. The next finding is that compared to domestic stock ownership, foreign share ownership has fewer problems due to the financial crisis, although spending on fixed asset investment is lower than local share ownership.

\section{RESEARCH METHOD}

Primary This study uses annual financial report data from 100 companies in the manufacturing sector listed on the Indonesia Stock Exchange (IDX) from 2007 to 2016. 100 company samples were obtained after some sorting / selection with several criteria such as: completeness of financial report data, registered in IDX during the period 2007 to 2016 . Data were analyzed using dynamic data panel regression, with investment as the dependent variable. While for the independent variables there are foreign ownership variables, cash flow, Sales, leverage, and Tobin Q. 
Table 1. Operational variable

\begin{tabular}{ll}
\hline Variables & Descriptions \\
\hline I & $\begin{array}{l}\text { Net investment }(\mathrm{I}) / \text { lag of net fixed assets }(\mathrm{K})=\{\text { Capital expenditure-Depreciation }\} / \text { fixed assets at } \\
\text { the beginning of the year. }\end{array}$ \\
CF & $\begin{array}{l}\text { Operational cashflow divided by asset book value. } \\
\text { Market value in equity, minus book value in equity, plus book value on assets, and all divided by } \\
\text { TQ }\end{array}$ \\
& Sook value on assets. \\
SALES & Liabilities/assets. \\
LEV & Dummy variable equals 1 if foreign ownership is more than $10 \%$. \\
D_own &
\end{tabular}

This study aims to analyze the agency problem in investment decision of manufacturing industry in Indonesia by considering foreign ownership. The D_own variable sees foreign share ownership if the company has $10 \%$ or more foreign shareholders. This refers to the provisions of the Organization for Economic Co-operation and Development (OECD) regarding direct investment enterprise, where foreign investors who have 10 percent (or more) share ownership in a company have the power and voting rights that can influence the company's decision.

The analysis method used in this study is dynamic panel data regression method. The model in this study is a model modification that refers to previous research conducted by Jiang et al. (2015), Chen (2013), and Aivazian (2005).

\subsection{The basic model of agency problems in investment decisions}

Cash flow $\left(\mathrm{CF}_{\mathrm{it}}\right)$ and Tobin $\mathrm{Q}\left(\mathrm{TQ}_{\mathrm{it}-1}\right)$ variables are the control variables used in this study, which is a control variable that refers to the research of Jiang et al. (2015), Chen (2013), and Aivazian (2005) to see factors that influence investment decisions.

$$
\begin{gathered}
I_{i t}=\gamma_{0}+\gamma_{1} I_{i t-1}+\gamma_{2} C F_{i t}+\gamma_{3} T Q_{i t-1}+\gamma_{4} \text { Lev }_{i t-1}+\gamma_{5} \text { Sale }_{i t-1}+\varepsilon_{i t} \\
\gamma_{1}>0, \gamma_{2}>0, \gamma_{3}>0, \gamma_{4}<0, \gamma_{5}>0
\end{gathered}
$$

\subsection{Model of the influence of agency problems in investment decisions by considering the foregn ownership}

The regression model used refers to Chen's (2013) research. While in the second model there is a D_own it $_{\text {variable that }}$ is interacted with Tobin Q and Leverage to see whether the share ownership rate (dummy) by foreign investors is greater than $10 \%$ strengthening the influence of investment opportunities $\left(\mathrm{TQ}_{\mathrm{it}-1}\right)$ and corporate control $\left(\mathrm{Lev}_{\mathrm{it}-1}\right)$ on investment decisions $\left(\mathrm{I}_{\mathrm{it}}\right)$.

$$
\begin{gathered}
I_{i t}=\delta_{0}+\delta_{1} I_{i t-1}+\delta_{2} C F_{i t}+\delta_{3} T Q_{i t-1}+\delta_{4} L^{2} v_{i t-1}+\delta_{5} \text { Sale }_{i t-1}+\delta_{6} D_{-} o w n_{i t}+\delta_{7} D_{-} o w n_{i t} * T Q_{i t-1}+\delta_{8} D_{-} o w n_{i t} * L e v_{i t-1}+\varepsilon_{i t} \\
\delta_{1}>0, \delta_{2}>0, \delta_{3}>0, \delta_{4}<0, \delta_{5}>0, \delta_{6}>0, \delta_{7}<0, \delta_{8}<0
\end{gathered}
$$

\section{FINDINGS AND DISCUSSIONS}

\subsection{Overview of inter-variable relations}

Scatter plot of the relationships between variables carried out before analyzing the investment decisions of manufacturing companies listed on the Indonesia Stock Exchange, to see the relationship between explanatory variables used with investment variables. The analysis was carried out using the Mini Tab software. The plot of the relationship between explanatory variables on investment using the linear trend will then be proven by analyzing the dynamic panel data in the subsequent analysis.

Figure 1 presents a pattern of relationships between explanatory variables with investment variables divided into four quadrants in each variable combination. Quadrants one and three show negative relation patterns between variables while quadrants two and four show positive relation patterns. Data distribution on the relationship between cash flow and investment in a sample of companies shows a positive trend in the relationship patterns. Then the distribution data on the relationship pattern between Tobin $q$ and investment in the sample examined is in quadrants one and three so that it shows a positive trend. The distribution data on the relationship pattern between sales with the majority investment is in quadrants one and three which show a positive trend. While the pattern of the relationship between leverage and investment has the majority of data distribution in quadrants 2 and 4 which show a negative trend. 


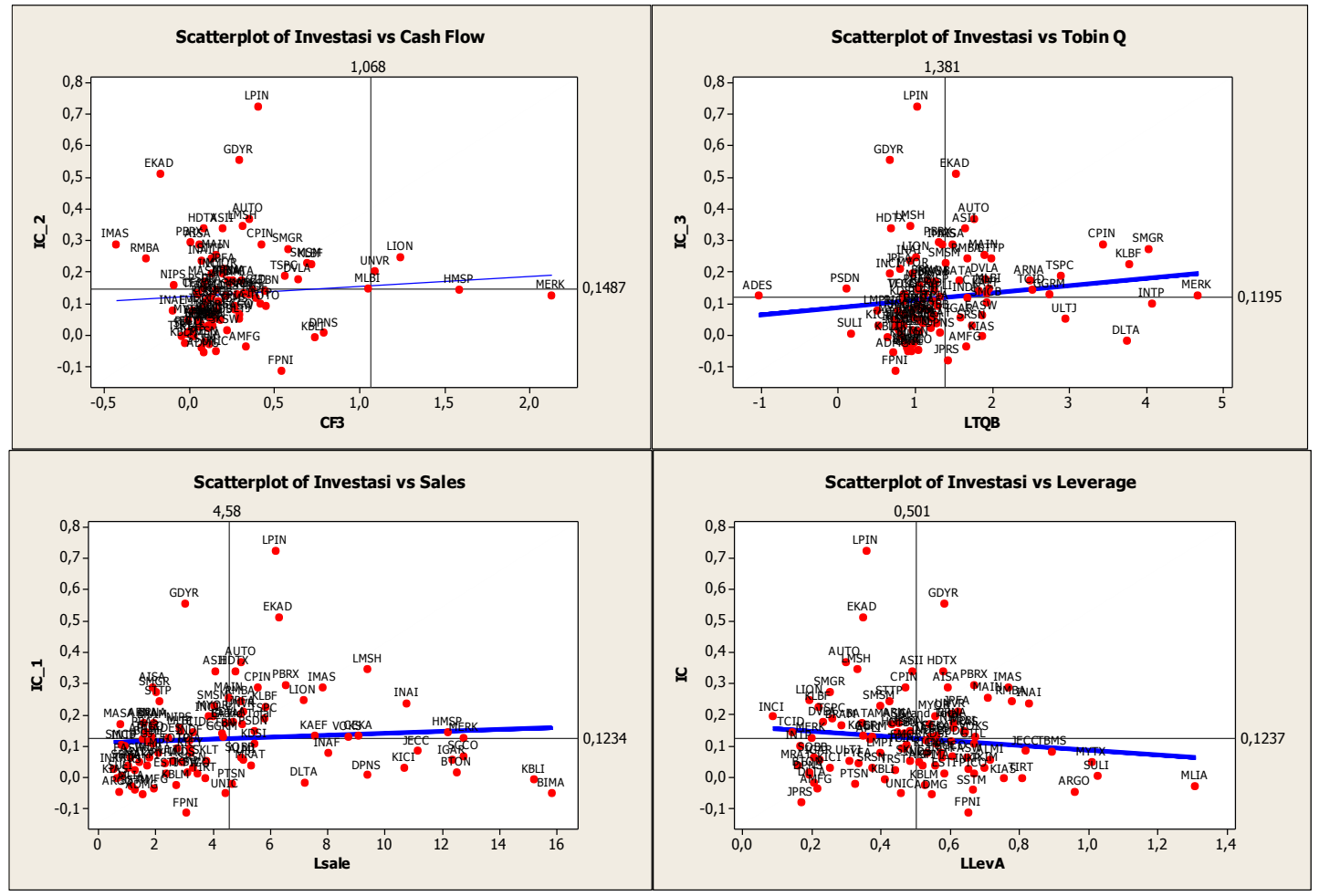

Figure 1 Inter-Variable Relations Plot

\subsection{Agency Problems Affect the Investment Decisions in Manufacturing Company}

Jensen and Meckling (1976) describe the agency relationship in agency theory that a company is a nexus of contract between owners of economic resources (principal) and managers (agents) who take care of the use and control of these resources. The model estimation results in Table 2 show that the investment variable it-1 $_{1}$ has a positive and significant impact on the investment of manufacturing companies, assuming ceteris paribus. Demarzo et al (2012) added that the emergence of agency problems will limit the company's investment, so there needs to be an optimal contract between investors and corporate agents in order to minimize the costs of agency problems.

$\mathrm{CF}_{\text {it }}$ has a positive and significant impact on investment in manufacturing companies. This shows that the greater in the cash flow shows the higher liquidity in the company will have an impact on increasing the company's investment, assuming ceteris paribus. Company with a higher cash flow will increase the conflict of interest between managers and shareholders, where managers tend to use the cash for investment rather than distributing it in the form of dividends to shareholders. These results are related with the research of Chen et al (2015) and Jiang et al (2015), where companies that have high cash flow have a high impact on their investment.

$\mathrm{TQ}_{\mathrm{it}-1}$ has a positive and significant impact on the investment of a manufacturing company. This shows that the higher investment opportunities will have an impact on increasing investment in manufacturing companies, assuming ceteris paribus. Martin (1996) explains that investment opportunities will increase the use of financing from corporate shares, where equity financing shows the potential for lower constraints on managers, thus giving them increased flexibility in current investments and future financing plans.

Sales $_{\mathrm{it-1}}$ becomes a proxy for market demand which has a positive and significant impact on the investment of manufacturing companies. If market demand increases, the company will get more revenue which later be used as an additional investment, then the investment in manufacturing companies will increase, ceteris paribus. Fuss and Vermeulen (2004) added to the results of research conducted, where sales growth was significant at 1 percent level. This shows that companies change their investment decisions in response to grow their demand. Fuss and Vermeulen (2004) added that new information about the company's fundamentals (sales growth) is used as a signal to invest (incentive for investment), so that the company's investment will increase 
Table 2 The estimation results of the agency problem model on investment in manufacturing companies in Indonesia

\begin{tabular}{|c|c|}
\hline Variables & Basic Model \\
\hline Investment $_{\text {it- } 1}$ & $0.0093 * * *$ \\
\hline $\mathrm{CF}_{\mathrm{it}}$ & $0.0779 * * *$ \\
\hline $\mathrm{TQ}_{\mathrm{it}-1}$ & $0.0196 * * *$ \\
\hline Salesit-1 & $0.0364 * * *$ \\
\hline Levit-1 $_{\text {it }}$ & $-0.3027 * * *$ \\
\hline Cons & 0.0294 \\
\hline Sargan (Prob) & 0.4250 \\
\hline Arelano bond M1 (Prob) & 0.0138 \\
\hline Arelano bond M2 (Prob) & 0.1392 \\
\hline Investment $_{\mathrm{t}-1}(\mathrm{FEM})$ & 0.0024 \\
\hline Investment $_{\mathrm{t}-1}(\mathrm{PLS})$ & 0.0094 \\
\hline
\end{tabular}

Note :

Symbols *,**,*** show significance at $10 \%, 5 \%, 1 \%$ confidence level

$\operatorname{Lev}_{\text {it-1 }}$ has a negative and significant impact on investment in manufacturing companies. The higher control of management will reduce investment because management will make investments that are believed to provide positive Net Present Value (NPV), assuming ceteris paribus. Related with Anwar and Sun (2014), Aivazian et al. (2005) who examined that leverage is negatively related to investment and that this negative effect is significantly stronger for companies with low growth opportunities compared to high growth opportunities.

\subsection{Agency Problem Affect the Investment Decision in Manufacturing Company by Considering Foreign Ownership}

Table 3 summarize the estimation result of the dynamic panel model for quantitative verification of the problem of the influence of foreign ownership on investment in manufacturing companies in Indonesia. The estimation results in Table 3 (specification 1) show that the D_own ${ }_{\text {it }}$ variable does not have a significant effect on the investment of the manufacturing company. Ownership of foreign shares does not directly affect investment decisions.

Table 3 The estimation results of the impact of agency problems in investment decisions by considering the ownership of shares by foreign investors

\begin{tabular}{|c|c|c|}
\hline Variables & Specification 1 & Specification 2 \\
\hline Investment $_{\text {it- } 1}$ & $0.0095 * * *$ & $0.0093 * * *$ \\
\hline $\mathrm{CF}_{\text {it }}$ & $0.0792 * * *$ & $0.0798 * * *$ \\
\hline $\mathrm{TQ}_{\mathrm{it}-1}$ & $0.0439 * * *$ & $0.0211 * * *$ \\
\hline Sales $_{\text {it-1 }}$ & $0.0371 * * *$ & $0.0379 * * *$ \\
\hline $\operatorname{Lev}_{\text {it- }-1}$ & $-0.3087 * * *$ & $-0.2334 * * *$ \\
\hline D_own & 0.0193 & 0.0436 \\
\hline D_own ${ }_{\text {it }} * T Q_{\text {it-1 }}$ & $-0.0301 * *$ & - \\
\hline D_own ${ }_{\text {it }} * \operatorname{Lev}_{\text {it }-1}$ & - & $-0.0980 * * *$ \\
\hline Cons & 0.0099 & -0.0108 \\
\hline Sargan (Prob) & 0.4421 & 0.4228 \\
\hline Arelano bond M1 (Prob) & 0.0134 & 0.0132 \\
\hline Arelano bond M2 (Prob) & 0.1415 & 0.1541 \\
\hline Investment $_{\mathrm{t}-1}(\mathrm{FEM})$ & 0.0024 & 0.0024 \\
\hline Investment $_{\mathrm{t}-1}(\mathrm{PLS})$ & 0.0098 & 0.0098 \\
\hline
\end{tabular}

Notes :

Symbols $* * *, * * *$ show significance at $10 \%, 5 \%, 1 \%$ confidence level

Specifications 1: Model to see the effect of financing through the capital market on investment of manufacturing companies with share ownership by foreign investors

Specifications 2: Model to see the effect of leverage (financing through debt) on investment of manufacturing companies with ownership of shares by foreign investors

The results of the $\mathrm{D}_{-} \mathrm{own}_{\mathrm{it}} * \mathrm{TQ} \mathrm{Qt}_{\mathrm{it}-1}$ variable show a negative and significant impact indicating that companies with foreign share ownership have the financing effect from the capital market on lower investments. Financing through the 
capital market will increase as the asymmetric information increases (Myer and Majluf 1948). Foreign ownership will improve good governance and reduce asymmetric information in the company (Stein 2003).

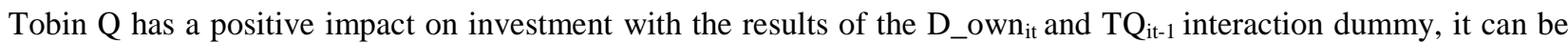
seen that foreign ownership affecting managerial control will weaken Tobin's Q impact. The weakening of Tobin's Q impact proves that companies with foreign ownership will prioritize funding other, except equity financing from the capital market in Indonesia, such as using funding from its parent companies abroad rather than seeking equity funding from the domestic capital market. Managers will be more selective in choosing investments, especially in positive NPVs to prevent overinvestment.

The estimation results in Table 3 (specification 2), where D_own it $* \mathrm{Lev}_{\mathrm{it}-1}$ variable shows a negative and significant impact, that means control over management will be more effective, where foreign ownership will increase the impact of corporate control in order to push the investment. This is related with the previous literature by Csermely and Vincze (2000) where foreign ownership in an industry provides a positive signal in better knowledge. The previous literature by Khanna and Palepu (1999) show that control over company management is better so that investment becomes lower in companies with foreign ownership.

The results comparation between previous subchapter related to leverage that negatively affect investment with the

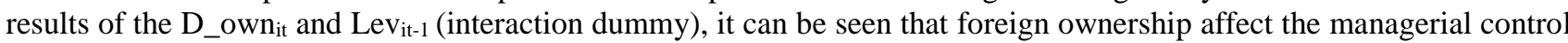
will strengthen leverage. Foreign ownership shares in a company will strengthen the sensitivity of leverage or external funding through debt as a proxy for control over management of investment in manufacturing companies in Indonesia. These results indicate that companies with foreign ownership will be more careful, especially when companies are investing using external financing.

\section{CONCLUSION}

The agency problems occur in manufacturing companies in Indonesia. Agency problems will not affect the control pattern in managers but tend to affect investment opportunities and availability of funds in the company. Foreign ownership as a proxy for Good corporate governance does not directly affect investment decisions in manufacturing companies in Indonesia. However, foreign ownership can weaken the influence of capital market funding and strengthen the influence of debt financing which shows increased control over management.

\section{REFERENCES}

[1] [IDX] Indonesian Stock Exchange. 2015. Capital Market Statistics [Internet]. [Downloaded 2016 Jan 7]. Available at : Http://www.idx.co.id/id Id/Beranda/Publikasi/Statistik.Aspx

[2] [BKPM]. Capital Investment Coordinating Board. 2015. Investment in Indonesia. [Internet]. [downloaded 2016 September 15]. Available at:http://www.bkpm.go.id/id/investasi-di-indonesia/statistik

[3] Aivazian V, Ge Y, Qiu J. 2003. The impact of leverage on firm investment: Canadian evidence. Journal of Corporate Finance. 11(1-2): 277-291. Doi:10.1016/S0929-1199(03)00062-2

[4] Aivazian V, Ge Y, Qiu J. 2005. The impact of leverage on firm investment: Canadian evidence. Journal of Corporate Finance. Doi:10.1016/S0929-1199(03)00062-2

[5] Ammann M, Oesch D, Schmid MM. 2013. Product market competition, corporate governance, and firm value: evidence from the EU-Area. European Financial Management. 19(3): 452-469. doi: 10.1111/j.1468-036X.2010.00605.x

[6] Andreou PC, Karasamani I, Louca C, Enrlich D, (2017), “The impact of managerial ability on crisis-period corporate investment". Journal of Business Research. Vol. 79, pp 107-122.

[7] Anwar S, Sun S.2014. Can the presence of foreign investment affect the capital structure of domestic firms?. Journal of Corporate Finance. doi: 10.1016/j.jcorpfin.2014.11.003.

[8] Arnold JM, Javorcik BS. 2009. Gifted kids or pushy parents? Foreign direct investment and plant productivity in Indonesia. Journal of International Economics. 79 (1): $42-53$.

[9] Brigham EF, Houston JF. 2009. Fundamentals of Financial Management, 12th Edition. United State Of America (USA): South Western Cengage Learning.

[10] Buckley PJ, Wang C, Clegg J. The impact of foreign ownership, local ownership and industry characteristics on spillover benefits from foreign direct investment in China. International Business Review. $16: 142-158$.

[11] Byun HS, Lee JH, Park KS. 2012. How does product market competition interact with internal corporate governance?: evidence from the Korean economy. Asia-Pacific Journal of Financial Studies. 41(4): 377-423 doi:10.1111/j.2041-6156.2012.01077

[12] Chen C, Li L, Ma MLZ. 2014. Product market competition and the cost of equity capital: evidence from China. AsiaPacific Journal of Accounting \& Economics. 21(3): 227-261. 
[13] Chen R, Ghoul AE, Omrani G, Wang H. 2013. Do state and foreign ownership affect investment efficiency? Evidence from Privatizations. Journal of Corporate Finance. 42: 408-421. doi: 10.1016/j.jcorpfin.2014.09.001

[14] Chen X, Sun Y, Xu X. 2015. Free Cash Flow, Over-Investment and Corporate Governance in China. Pacific-Basin Finance Journal.doi: 10.1016/j.pacfin.2015.06.003

[15] Demarzo PM, Fishman MJ, He Z, dan Wang N. 2012. Dynamic agency and the q theory of investment. The Journal of The American Finance Association. LXVII(6): 2295-2340.

[16] Dwor-Frecaut, D., Colaco, F., Hallward-Driemeier, M. (Eds.), 2000. Asian Corporate Recovery: Findings from FirmLevel Surveys in Five Countries. The World Bank, Washington, DC.

[17] Eisenhard KM. 1989. Agency theory: an assessment and review. Academy of Management Review. 14 (1): $57-74$.

[18] Fazzari, S., Hubbard, R.G., Petersen, B., (1988), "Financing constraints and corporate investment", Brooking Papers on Economic Activity, Vol. 1, pp. 141-195.

[19] Fuss C and Vermeulen P. 2004. Firms investment decisions in response to demand and price uncertainty. ECB Working Paper Series. 347

[20] Guariglia A, Yang J. 2015. A balancing act: Managing financial constraints and agency costs to minimize investment inefficiency in the Chinese market. Journal of Corporate Finance doi: 10.1016/j.jcorpfin.2015.10.006.

[21] Hidayat R. 2010. Investment Decisions and Financial Constraints: Empirical Studies on the Indonesia Stock Exchange.Bulletin of Monetary and Banking Economics :457-479

[22] Jensen, M.C., Meckling, W.H., 1976. Theory of the firm: managerial behavior, agency cost and ownership structure. Journal of Financial Economics 3, 305- 360.

[23] Jiang F, Kim KA, Nofsinger JR, Zhu B. 2015. Product market competition and corporate investment: evidence from China. Journal of Corporate Finance. 35: 19-210. doi: 10.1016/J.Jcorpfin.2015.09.004.

[24] Khana, Tarun, dan Krishna P. 1999. Emerging Market Business Groups, Foreign Investor, and Coorporate Governance. National Bureau of Economic Research Working Paper 6695.

[25] Limanli O. 2015. Determinants of R\&D Investment Decision in Turkey. Social and Behavioral Sciences. 195 :759767.

[26] Lin C, Ma Y, Xuan Y. 2011. Ownership structure and financial constraints: Evidence from a structural estimation. Journal of Financial Economics. $102: 416-431$

[27] Martin JK. 1996. The method of payment in corporate acquisitions, investment opportunities, and management ownership. The Journal of Finance. LI(4): 1127-1246.

[28] Messier, W.F, S.M.Glover and D.F. Prawitt. 2006. Auditing and Assurance ServicesA Systematic Approach. Fourth Edition. McGrw-Hill Companies,Inc. New York.

[29] Mydans, S., 1998. Indonesia begins the rescue and consolidation of banks. The New York Times, D2.

[30] OECD. 2001. Direct investment enterprise. https://stats.oecd.org/glossary/detail.asp?ID=622

[31] Prasetyantoko, A., (2007), "Foreign ownership and firm financing constraint in Indonesia". Atma Jaya Catholic Univesity, Jakarta, ENS-LSH, in agreement with ESCP EAP, The European School of Management, GATE

[32] Scott AJ. 1997. The cultural economy of cities. International Journal of Urban and Regional Research. Doi10.1111/1468-2427.00075

[33] Shin HH, Kim YH. (2002). Agency costs and efficiency of business capital investment: evidence from quarterly capital expenditures. Journal of Corporate Finance. 8(2): 139-158.

[34] Stein JC. 2003. Agency, Information and Corporate Investmnent. Handbook of the Economics of Finance. 111-124.

[35] Vranakis, S.K., Chatzoglou, P., (2012), "A conceptual model for machinery \& equipment investment decisions". International Journal of Business and Management. Vol 7 No. 1, pp 36-56.

[36] Zhou YM, Li X, Svenjnar J. (2011). Subsidiary divestiture and acquisition in a financial crisis: Operational focus, financial constraints, and ownership. Journal of Corporate Finance. 17 :272-287 